\title{
THE EFFECT OF CORPORATE GOVERNANCE ON RETURN OF STOCK PRICE WITH COMPANY SIZE AS CONTROL VARIABLE
}

\author{
I Gusti Bagus Yosia Wiryakusuma \\ Universitas Ciputra, UC Town, Citraland, Surabaya 60219, Indonesia
}

\begin{abstract}
Good Corporate Governance (GCG) has a close relationship with public trust in a company. When a company implements GCG, it will provide security to shareholders. The safer shareholders feel, the more likely it will be for them to invest funds into the company sustainably. This should stabilize the company's stock price. This study aims to examine the effect of GCG on stock price returns. In this study, secondary data was used, and linear regression was used to test the effect. The results of this study indicate that GCG has no effect on stock price returns.
\end{abstract}

Keywords: corporate governance, good corporate governance, return, stock price

\section{BACKGROUND}

Corporate Governance is one of the most important economic pillars (Budiharjo, 2019). Corporate governance is the relationship between the stakeholders in determining the direction to be taken by the company. According to Pratiwi and Suryanawa (2014), Good Corporate Governance (GCG) is one of the pillars of the market economy system. GCG has a close relationship with public trust in the company. When a company implements GCG, it will provide a sense of security to shareholders. The company's goal in implementing GCG is to optimize the profitability of all stakeholders in the long run. The Indonesian Institute for Corporate Governance (IICG) is an institution formed to monitor the implementation of GCG in Indonesia. IICG ranks companies that implement GCG in Indonesia. The results of the commemoration conducted by the IICG are

\footnotetext{
*Corresponding Author.

e-mail: bagus.yosia@ciputra.ac.id
} 
referred to as the Corporate Governance Perception Index (CGPI). Retno and Priantinah (2012) found in their research that GCG affects stock prices.

Stocks are one of the financial instruments in the capital market that can be traded to other parties. The price of a company's stock is called the stock price. Stock prices can be influenced by several factors, such as the number of requests and offers for these shares. The better the implementation of GCG, the more shareholders will trust in investing funds in the company. This will make the company's share price more stable. This is reinforced by research conducted by Bandiyono (2019), which states that corporate governance has a positive influence on firm value.

Based on the existing background, this research will discuss "The Effect of Corporate Governance on Stock Price Returns with Company Size as Control Variables.”

\section{THEORETICAL BASIS}

\subsection{Good Corporate Governance (GCG)}

Corporate governance is the relationship between the stakeholders in determining the direction to be taken by the company. Corporate Governance is one of the most important economic pillars (Budiharjo, 2019). According to Bandiyono (2019), the implementation of GCG is expected to increase the value of the company. GCG aims to direct companies to achieve a balance between rights and obligations.

\subsection{The Indonesian Institute for Corporate Governance (IICG)}

In order to regulate the application of GCG in Indonesia, the Indonesian Institute for Corporate Governance (IICG) was formed. IICG aims to popularize GCG in Indonesia. In addition to regulating the implementation of GCG in Indonesia, IICG also ranks companies that implement GCG.

\subsection{Corporate Governance Perception Index (CGPI)}

The results of the ranking that has been carried out by the IICG are referred to as the Corporate Governance Perception Index (CGPI). CGPI is the result of 
ranking GCG implementation in companies listed on the Indonesia Stock Exchange.

\subsection{Stock Price Return}

One financial instrument that can be traded to other parties is stock. Stock is proof of company ownership. The share price is the price of a company's stock. Stock prices can be influenced by several factors, such as demand and supply for these shares. Stock return is the percentage of profit derived from stock investment. According to Hartono (2014), returns can be divided into two, namely realized returns where returns have occurred and expected returns that are predicted to happen. The return formula is shown below (Hartono, 2014):

$$
\text { Return }=\text { Capital gain }(\text { loss })+\text { Yield }
$$

Capital gain (or loss) is the difference between current market price and past period market price (Hartono, 2014).

$$
\text { Capital gain }(\text { loss })=\frac{P_{t}-P_{t-1}}{P_{t-1}}
$$

\subsection{Company Size}

The size of the company (size) is formulated as follows (Retno and Priantinah, 2012):

$$
\text { Size }=\log (\text { Total Assets })
$$

\subsection{Market Capitalization}

The market capitalization of a company is the multiplication of the market price of the company's shares with the number of shares outstanding. Market capitalization is formulated below (Ross, 2015):

Market Capitalization $=$ Price per share $\times$ Shares outstanding

\subsection{Regression Analysis}

According to Ariefianto (2012), regression analysis revealed the relationship between variables by including the element of causality. Regression analysis is 
divided into 2, namely simple linear regression analysis, where there is one independent variable and one dependent variable, and multiple linear regression analysis, where there is one dependent variable with more than one independent variable.

\subsection{Past Researches}

Nuswandari (2009), in his research, found that GCG can affect a company's stock price within a certain period. In addition, research conducted by Alexakis (2011) stated that the stock price returns of companies that implement GCG have increased. According to Peni and Vähämaa (2011), a Bank that implements GCG should have a high stock return. This is reinforced by the results of the research conducted by Wiryakusuma (2019), which stated that stock price volatility is influenced by GCG. The better the implementation of GCG by a company, the higher the value of the company. GCG implementation is expected to increase company value (Bandiyono, 2019).

\subsection{Research Framework}

The relationship between the variables used in this study is shown in Figure 1 below:

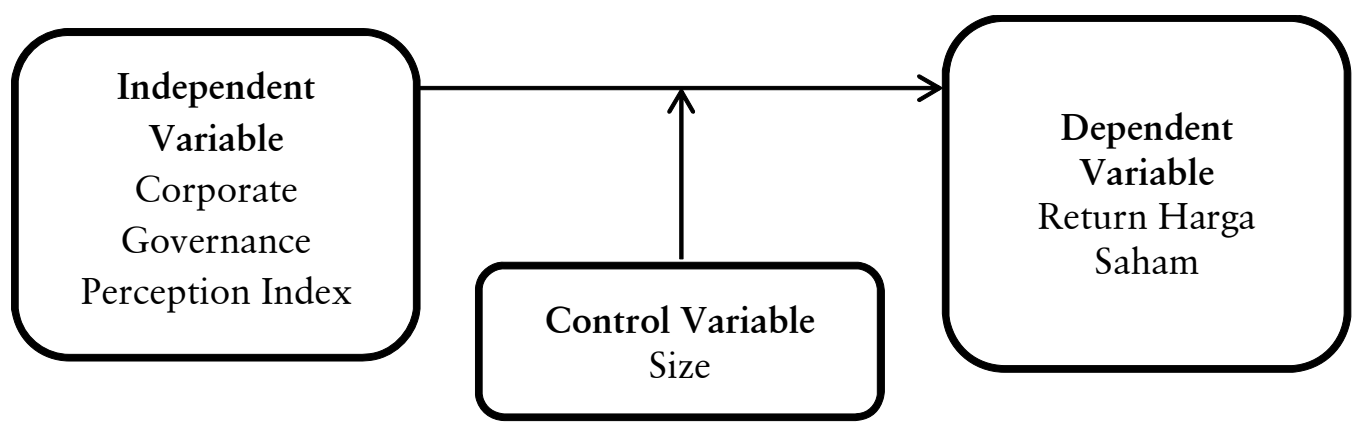

Figure 1 Framework

Based on the results of previous studies, the hypotheses in this study are as follows:

H1: Corporate Governance Perception Index (CGPI) affects the company's stock price return. 


\section{RESEARCH METHODOLOGY}

\subsection{Population and Sample}

The population is a collection of elements that have specific characteristics so that it can be used to draw conclusions. The sample is a collection of selected elements in the population (Sanusi, 2011). In this study, the population used is all companies listed on the IDX. The sample used in this study are companies listed on the IDX and have applied GCG for five consecutive years in 20102014.

\subsection{Data Collecting Method}

Study documentation is used to collect data in this study. Data in this study were obtained from Yahoo Finance, IDX, and IICG.

\subsection{Data Analysis Method}

\subsubsection{Double Linear regression}

According to Sugiarto (1992), estimating the regression parameters for multiple regression models is essentially just an extension of the concept of simple linear regression. In multiple linear regression, there is more than one variable. The multiple linear regression model can be formulated as (Sugiarto, 1992):

$$
Y_{i}=\beta_{0}+\beta_{1} X_{1 i}+\beta_{2} X_{2 i}+\cdots+\beta_{k} X_{k i}+\varepsilon_{i}
$$

Information:

$i=1,2, \ldots, n$

$\beta_{0}=$ intersection (the point of intersection between the regression line and the Y-axis)

$\beta_{j}=$ partial regression coefficient for $X_{1}, X_{2}, \ldots, X_{k}$, with $j=1,2, \ldots, k$

$\varepsilon_{i}=$ error

$k=$ the number of explanatory variables in the model

$n=$ number of observations 


\subsubsection{Hypothesis test}

The research hypothesis will be tested with the following regression equation:

$$
\text { Return }=\beta_{0}+\beta_{1} \text { CGPI }+\beta_{2} \text { Size }+\beta_{3}(\text { CGPI } \times \text { Size })+\varepsilon
$$

Information:

CGPI = Corporate Governance Perception Index

Return $=$ Stock price return of sample company while participating in GCG

Size $=\log$ (market capitalization)

$\beta_{0} \quad=$ Constant

$\beta_{i} \quad=$ Regression coefficient (with $i=1,2,3,4$ )

$\varepsilon \quad=$ Error

The significance level (á) is chosen at $5 \%$ or 0.05 . The significance level is used for testing. The criteria supported or not supported by the hypothesis are as follows:

a. If the significance level is $\leq 0.05$, it can be said that the hypothesis is supported, which means that the independent variable significantly influences the dependent variable.

b. If the significance level is $>0.05$, it can be said that the hypothesis is not supported, which means that the independent variable does not significantly influence the dependent variable.

\section{RESEARCH RESULTS AND DISCUSSION}

\subsection{Descriptive Statistics Test}

Descriptive statistics are used to illustrate the sample data profile. In this research, descriptive statistics are shown with the following results:

Table 1 Descriptive Statistics

\begin{tabular}{lccccc}
\hline & $\mathbf{N}$ & Minimum & Maximum & Mean & Std. Deviation \\
\hline \hline CGPI & 35 & 70,73 & 92,88 & 85,37 & 4,56 \\
Return & 35 & $-45,00$ & 84,46 & 14,74 & 29,66 \\
Size & 35 & 12,86 & 14,40 & 13,46 & 0,47 \\
Valid N & 31 & & & &
\end{tabular}

Source: Processed data (2019) 
In Table 1, the results show that the CGPI variable has 35 respondents with a maximum value of 92.88 and a minimum value of 70.73 . The average CGPI value of the number of respondents is 85.37 , with a standard deviation of 4.56 . The maximum and minimum values of the return variable are 84.46 and -45.00 , while the average value and standard deviation of the return variable are 14.74 and 29.66. The company's size variable has an average of 13.46, with a standard deviation of 0.467 . The maximum and minimum values of variable size are 14.40 and 12.80 , with a total data of 35 .

\subsection{Regression Test}

\subsubsection{Classical assumption test}

The classic assumption test aims to see whether there is data normality, multicollinearity, autocorrelation, and heteroscedasticity in the regression model. A good linear regression model must have normally distributed data and not have multicollinearity, autocorrelation, or heteroscedasticity.

\subsubsection{Normality test}

A normality test is used to test whether the data is normally distributed or not. (Priyatno, 2014). The results of the normality test are shown in the following table:

Table 2 Normality Test

\begin{tabular}{lr}
\hline & Unstandardized Residual \\
\hline \hline $\mathrm{N}$ & 35 \\
Asymp. Sig. (2-tailed) & 0,980 \\
\hline
\end{tabular}

Source: Processed data (2019)

In Table 2, it can be seen that the significance value (Asymp. Sig. (2-tailed)) of residual return has a value of 0.980 . If the significance value is greater than 0.05 , then the residual value is normally distributed. 


\subsubsection{Multicollinearity Test}

Multicollinearity test is used to look for a perfect or near-perfect linear relationship in the regression model (the correlation coefficient is high or even 1) (Priyatno, 2014). The better the regression model, then there should be no perfect or near-perfect correlation between the independent variables (Priyatno, 2014). The results of the multicollinearity test are shown in the following table:

Table 3 Multicollinearity Test

\begin{tabular}{lccc}
\hline \multicolumn{1}{c}{ Variable } & Tolerance & VIF & Remarks \\
\hline \hline CGPI & 0,374 & 2,677 & No multicollinearity \\
CGPI.Size & 0,374 & 2,677 & No multicollinearity \\
\hline
\end{tabular}

Source: Processed data (2019)

In Table 3, it can be seen that the value of tolerance is 0.374 , and the value of VIF is 2.677. The tolerance value is more than 0.1 , and the VIF value is less than 10 , so it can be stated that there is no multicollinearity.

\subsubsection{Autocorrelation Test}

The autocorrelation test aims to see whether there is a correlation between observational elements arranged according to time or place. A good regression model should not have any autocorrelation (Priyatno, 2014). The results of the autocorrelation test are shown in the following table:

Table 4 Autocorrelation test

\begin{tabular}{lc}
\hline & \multicolumn{2}{c}{$\begin{array}{c}\text { Unstandardized } \\
\text { Residual }\end{array}$} \\
\hline \hline Asymp. Sig. (2-tailed) & 1,00 \\
\hline
\end{tabular}

Source: Processed data (2019)

Based on Table 4, the Asymp. value Sig. (2-tailed) obtained is 1.00, so that it can be said that autocorrelation did not occur. 
I Gusti Bagus Yosia Wiryakusuma / The Effect of Corporate Governance on Return of Stock Price with Company Size as Control Variable

\subsubsection{Heteroscedasticity Test}

A good regression model does not have heteroscedasticity (Priyatno, 2014). Heteroscedasticity is a residual variance that is different in all observations of the regression model. The test results are shown in the following table:

Table 5 Heteroscedasticity Test

\begin{tabular}{llccc}
\hline & & CGPI & Size & CGPI.Size \\
\hline \hline $\begin{array}{l}\text { Unstandardized } \\
\text { Residual }\end{array}$ & $\begin{array}{l}\text { Sig. (2- } \\
\text { tailed) }\end{array}$ & 0,96 & 0,98 & 1,00 \\
\hline
\end{tabular}

Source: Processed data (2019)

In Table 5, it can be seen that the significance value of the independent variables is more than 0.05 . So it can be concluded that there was no heteroscedasticity.

\subsubsection{Linear regression analysis}

Linear regression analysis is used to determine the effect of a linear relationship between independent variables on the dependent variable. This study uses a simple linear regression analysis, which analyzes the linear relationship between 1 independent variable and one control variable with one dependent variable. The T-test is used to determine the effect of independent variables on the dependent variable. The results of the linear regression analysis are shown in the following table:

Table 6 Result of Linear Regression Analysis

\begin{tabular}{lcccc}
\hline \multirow{2}{*}{ Variable } & \multicolumn{2}{c}{ Unstandardized Coefficients } & t & Sig. \\
\hline \hline (Constant) & B & Std. Error & & \\
CGPI & 489,99 & 510,33 & 0,96 & 0,34 \\
CGPI.Size & $-452,84$ & 332,52 & $-1,36$ & 0,18 \\
\hline
\end{tabular}

Source: Processed data, (2019)

From Table 6 it can be seen that the CGPI variable has a significance value (Sig.) of 0.18 . 


\subsection{Discussion}

From the t-test that has been done, the results show that the significance value of CGPI is greater than 0.05. Thus, CGPI has no effect on return. However, in Table 6, the significance value of CGPI can be seen. The size is less than 0.05. This shows that when the CGPI variable is given the size control variable, the size variable will strengthen the CGPI variable, causing CGPI to affect the return but with size as the control variable. From the results of this study, it was found that $\mathrm{H} 1$ is not supported, the Corporate Governance Perception Index (CGPI) has no effect on the company's stock price returns. The results of this study support the researches conducted by Tjondro and Wilopo (2011) and Budiharjo (2016), which stated that GCG does not affect stock price returns.

\subsection{Managerial Implication}

This research proves that the application of GCG has no influence on stock price returns, but the implementation of GCG must always be carried out continuously in the organization. The application of GCG is done not only to increase stock price returns but is expected to provide a competitive advantage for the company.

For investors, although the application of GCG has no effect on stock price returns, it is expected that the application of GCG can be considered in selecting stocks. Investors are expected to consider not only short-term profits but also long-term.

\section{CONCLUSION AND SUGGESTIONS}

\subsection{Conclusion}

Based on research that has been done, the results show that corporate governance has no effect on stock price returns. This is reinforced by research conducted by Budiharjo (2016), which stated that stock price returns are not influenced by GCG applied to the company. Tjondro and Wilopo (2011) also stated that GCG does not affect stock price returns. This might happen due to many factors in determining stock prices, such as the law of supply and demand. 
I Gusti Bagus Yosia Wiryakusuma / The Effect of Corporate Governance on Return of Stock Price with Company Size as Control Variable

\subsection{Suggestions}

In this study, the variables used include CGPI, stock price returns, and company size. It is hoped that more diverse variables can be used in future studies.

\section{REFERENCES}

Ariefianto, M.D. 2012. Ekonometrika: Esensi dan Aplikasi dengan Menggunakan EVIEWS. Jakarta: Erlangga.

Alexakis, C.A., Balios, D., Papagelis, G., dan Xanthakis, M. 2006. An Empirical Investigation of The Visible Effects of Corporate Governance: The Case of Greece. Manajerial Finance, Vol. 32, No. 8, p.673-684.

Azmy, A., Anggreini, D.R., Hamim, M. 2019. Effect of Good Corporate Governance on Company Profitability RE \& Property Sector in Indonesia. Jurnal Akuntansi, Volume XXIII, No. 1, p 18-33.

Bandiyono, A. 2019. The Effect of Good Corporate Governance and Political Connection on Value Firm. Jurnal Akuntansi, Volume XXIII, No. 3, p333-348.

Bhagat, S. \& Bolton, B. 2019. Corporate Governance and Firm Performance: The Sequel. Journal of Corporate Finance, 58, p.142-168.

Budiharjo, R. 2016. Pengaruh Good Corporate Governance terhadap Return Saham dengan Profitabilitas sebagai Variabel Intervening dan Moderating. Jurnal TEKUN, Vol. 7, No. 1, p.80-98.

Budiharjo, R. 2019. Effect of Environmental Performance and Corporate Governance Structure on Financial Performance. International Journal of Academic Research in Accounting, Finance and Management Sciences, 9(2):11-22.

Daniri, M.A. 2005. Good Corporate Governance: Konsep dan Penerapannya dalam Konteks Indonesia. Jakarta: Ray Indonesia.

Hartono, J. 2014. Teori dan Praktik Portofolio dengan Excel. Jakarta: Salemba Empat. Kasmir. 2010. Pengantar Manajemen Keuangan. Jakarta: Kencana.

Lassoued, N., Elmir, A. 2011. Portfolio Selection: Does Corporate Governance Matter? Corporate Governance, Vol. 12, No. 5, p. 701-703.

Madura, J. 2015. International Financial Management, 12th Edition. Stamford: Cengage Learning. 
May, E. 2011. Smart Traders Not Gamblers. Jakarta: PT Gramedia Pustaka Utama. Narbuko, C. \& Achmadi, A. 2002. Metodologi Penelitian. Jakarta: PT Bumi Aksars. Nuswandari, C. 2009. Pengaruh Corporate Governance Perception Index Terhadap Kinerja Perusahaan pada Perusahaan yang Terdaftar di Bursa Efek Jakarta. Jurnal Bisnis dan Ekonomi (JBE), Vol. 16, No. 2, p. 70-84.

Peni, E., Vähämaa, S. 2011. Did Corporate Governance Improve Bank Performance during the Financial Crisis? Springer.

Retno, D.M. \& Priantinah, D. 2012. Pengaruh Good Corporate Governance dan Pengungkapan Corporate Social Responsibility terhadap Nilai Perusahaan (Studi Empiris pada Perusahaan yang Terdaftar di Bursa Efek Indonesia Periode 2007-2010). Jurnal Nominal, Vol. 1, No. 1.

Ross, S.A., Westerfield, R.W., Jaffe, J., Lim, J., Tan, R., \& Wong, H. 2015. Corporate Governance: Asia Global Edition. New York: McGraw-Hill Education.

Pratiwi, N. \& Suryanawa, I. Kt. 2014. Pengaruh Good Corporate Governance dan Corporate Social Responsibility Disclosure pada Return Harga Saham. EJurnal Akuntansi Universitas Udayana, 9.2 (2014); 465-475.

Priyatno, D. 2014. SPSS 22 Pengolah Data Terpraktis. Yogyakarta: Andi Offset.

Subramanyam, K.R. \& Wild, J.J. 2009. Financial Statement Analysis. Singapore: McGraw-Hill.

Sanusi, A. 2011. Metodologi Penelitian Bisnis. Jakarta: Salemba Empat.

Sugiarto. 1992. Tahap Awal + Aplikasi Analisis Regresi. Yogyakarta: Andy Offset. Sugiyanto, E.K. 2011. Peningkatan Return Saham dan Kinerja Keuangan melalui Corporate Social Responsibility dan Good Corporate Governance. Aset, Vol. 13, No.1, p. 47-56.

Sugiyono. 2009. Metode Penelitian Bisnis. Bandung: Penerbit: CV Alfabeta. Sukamulja, S. 2003. Good Corporate Governance di Sektor Keuangan Indonesia: Dampak GCG terhadap Kinerja Perusahaan (Kasus di Bursa Efek Jakarta). Benefit, Vol. 8 No. 1, p. 1-25.

Tjondro, D. \& Wilopo, R. 2011. Pengaruh Good Corporate Governance (GCG) terhadap Profitabilitas dan Kinerja Saham Perusahaan Perbankan yang Tercatat di Bursa Efek Indonesia. Journal of Business and Banking, Vol. 1, No. 1, p.1-14.

Wild, J.J., Subramanyam, K.R., \& Halsey, R.F. 2007. Financial Statement Analysis, Ninth Edition. Mc-Graw Hill. 
I Gusti Bagus Yosia Wiryakusuma / The Effect of Corporate Governance on Return of Stock Price with Company Size as Control Variable

Wiryakusuma, I.G.B.Y. 2019. Pengaruh Corporate Governance terhadap Volatilitas Harga Saham. JRAK, Vol. 15, No. 1, p. 1-10.

Zulfikar. 2006. Analisis Good Corporate Governance di Sektor Manufaktur:

Pengaruh Penerapan Good Corporate Governance, Return on Asset, dan Ukuran Perusahaan terhadap Nilai Pasar Perusahaan. Benefit, Vol. 10, No. 2, p. 130-141.

www.finance.yahoo.com

www.idx.co.id

www.investing.com 
Review of Management and Entrepreneurship

Volume 03, Number 01, April 2019 